harmful to the user, such as adulterated foods, ${ }^{28}$ or instruments of fraud, such as stolen cars $^{29}$ and misbranded articles, ${ }^{30}$ or with a comparatively insignificant traffic, such as convict-made goods. ${ }^{3 \mathrm{X}}$ Hammer v. Dagenhart, however, limited the power to prohibit in two ways: first by distinguishing the former cases sustaining federal prohibitions on the ground that they affected things harmful in themselves and producing harmful consequences at their destination; ${ }^{32}$ second, by declaring that the power could not be used to subject local industries, not themselves interstate commerce, to federal regulation. The requirement that the articles prohibited be harmful in themselves is avoided by cooperative legislation through the distinction pointed out above, i.e., the broader scope of the state power when it is permitted to act. The second objection, that state power will be destroyed by federal prohibitions based upon local manufacturing conditions, vanishes when the cooperative method is used. Federal enabling acts recognize and rely upon the individual states. No state could join in destroying the interstate market until it had adopted for its own industries such regulations as it demanded of others, for discriminatory state measures would be struck down. ${ }^{33}$ A substantial number of states would have to adopt prohibitory measures for themselves before a serious effect on the interstate market could be produced. The decision may supply a means, so far as constitutional theory can do so, of dealing with child labor without constitutional amendment.

\title{
THE VALIDITY OF STOCKHOLDERS' VOTING AGREEMENTS IN IILINOIS
}

Modern corporate financing frequently requires the creation of a united majority of stockholders, by a contract or trust, which will successfully resist both the attack of the original parties to the undertaking and the objections raised by transferees of the affected shares. The necessity of making binding agreements among stockholders arises upon the creation, the reorganization, or the winding up of a corporation; or in the securing of loans made to the corporation;

${ }^{28}$ Hipolite Egg Co. v. U.S., 220 U.S. 45 (IgII). Perhaps intoxicating liquors (Clark Distilling Co. v. Western Md. Ry. Co., 242 U.S. 3 II (IgI7); U.S. v. Hill, 248 U.S. 420 (I9Ig)) and prostitutes (Hoke v. U.S., 227 U.S. 308 (xg겨)) can also be included in this class.

29 Brooks v. U.S., 267 U.S. 432 (I925).

${ }^{30}$ Seven Cases v. U.S., 239 U.S. 5 I0 (Ig16); Weeks v. U.S., 245 U.S. 6I8 (IgI8).

${ }^{3 x}$ Whitfield v. Ohio, 56 Sup. Ct. $53^{2}$ (I936).

${ }^{32}$ The requirement that goods prohibited from interstate commerce by federal law be harmful in themselves was first used as a description, in supporting decisions sustaining the power to prohibit. The Lottery Case, I88 U.S. 321 (I903). In Clark Distilling Co. v. Western Md. Ry. Co., 242 U.S. 3 II (xgI7), the prohibition was sustained on the ground of the "exceptional" nature of the prohibited commodity-intoxicating liquor. In Hammer v. Dagenhart the harmful or exceptional nature of the commodities involved in the earlier cases became a basis for distinguishing them and so a limitation upon the federal power to prohibit.

33 Welton v. Missouri, 9r U.S. 275 (I876); Walling v. Michigan, II6 U.S. 446 (I886). 
or in refinancing by the issuance of new stock; or where the stockholders are split into two groups and wish to preserve the status quo of their balanced holdings.

\section{I}

Voting agreements are frequently open to attack on two distinct grounds. A contract among $\mathrm{A}, \mathrm{B}$, and $\mathrm{C}$, the majority stockholders, whereby $\mathrm{A}$ is given the right to vote their combined stock as a unit at all stockholders' meetings may be condemned for separating voting rights from the ownership of stock. If the contract further provides that A, B, and C shall be elected directors and officers at stated salaries, it may be subject to attack for interfering with the free exercise by the directors of their independent judgment in the management of the corporation. On the problem of the separation of voting rights from beneficial ownership, voting agreements are so nearly analogous to voting trusts that the two must be considered together.

A voting trust is created by a conveyance of the legal title of the shares of several stockholders to one or more persons for the purpose of voting them in order to control the corporation's business and affairs. ${ }^{x}$ Because it is a true equity trust, the usual requirements of trust law must be met; but since the sole purpose is the securing of corporate control, it must also be carefully scrutinized to see that nothing in the policy of corporation law invalidates it. The usual definition of a voting agreement is a contract among two or more stockholders whereby they retain not only the legal and beneficial ownership of their shares, but also their individual right to vote them, and merely agree to vote all their combined stock as a unit in a pre-determined way to accomplish some corporate purpose such as the election of directors. However, for the purpose of the present discussion, the term voting agreement is used in a broader sense to include also a transaction whereby the legal and beneficial owner of the stock sells, either wholly or partly, his right to vote. All voting trusts and voting agreements involve, to a greater or lesser extent, the separation of voting rights from the beneficial ownership of the stock. The sale of votes to outsiders is the clearest example. The next most obvious is the voting trust in which the cestuis do not direct the trustee. ${ }^{3}$ If the trustee is directed by the cestuis, there is a

${ }^{2} 5$ Fletcher, Corporations $\$ 2079$, p. 28I (r93I).

2 Where statutes expressly provide for the creation of voting trusts, perhaps the requirements of trust law need not be strictly fulfilled. 5 Fletcher, Corporations $\S 2079$, p. 28I (I93I). Voting trusts do not include trusts of stock in which the principal object is not that of controlling voting. 5 Fletcher, Corporations $\$ 2075$, p. 265 (I93I).

A voting trust is not an agency relationship as are proxies or reciprocal proxies. $14 \mathrm{C}$. J. $\$$ I420 (IgIg). For detailed discussions of voting trusts see 24 Mich. L. Rev. 344 (I926); 5 So. Calif. L. Rev. 214 (r932) (completely annotated); 22 Col. L. Rev. 627 (I922); 6 U. of Cin. L. Rev. 64 (I932); 40 Harv. L. Rev. Io6 (1926).

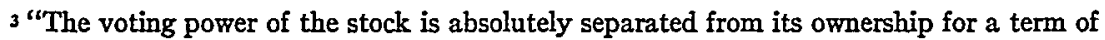
years, so that the real owners of the property are during that time entirely divested of its management and control or of any participation therein." Luthy v. Ream, $270 \mathrm{Ml}$. I7o, r77, Iro N.E. 373,375 (rgI5). 
strong resemblance to a voting contract in which the stockholders themselves vote in a way pre-determined by ballot among themselves. ${ }^{4}$ In each of the latter two, the separation of voting power from ownership is less complete; but both devices operate to prevent a free exercise of the voting rights of each participant therein if he subsequently desires to vote independently of the terms of the trust or contract. In such an event, a minority of all stockholders control the stockholders' meetings, against the statutory requirement that a majority vote shall prevail. The recognition of these gradations of separation becomesimportant in view of the apparent approval by the Illinois courts of the dogma that voting rights cannot be separated from the beneficial ownership of stock. 5

On an analogy to public elections it has been held that a stockholder cannot sell his vote and retain all the other incidents of ownership. ${ }^{6}$ Originally, the justification for this rule lay in the assumption that each stockholder is entitled to the honest and unbiased judgment of every other stockholder, expressed in his vote. But today the doctrine lacks merit because to impose such a duty upon the scattered stockholders of modern corporations is impracticable. 7 The doctrine is directly opposed to the well settled principle that every stockholder may vote as he thinks his personal interests are best served, and in those states which permit non-voting stock and voting trusts it is difficult to understand why a stockholder may not sell his vote if he wishes and yet retain his ownership of stock as an investment. Some states early recognized that the prohibition against the separation of voting rights from beneficial ownership was largely the result of an unrealistic public policy, ${ }^{8}$ and accordingly was not to be followed.9

4 See note $2 \mathrm{I}$ infra.

5 "The principle to be deduced from these cases [not Illinois] is that the ... power to vote is inherently attached to and inseparable from the real ownership of each share, and can only be delegated by proxy, with power of revocation; that each stockholder has the right to demand that every other stockholder, if he desires to do so, shall have the right to exercise at each annual meeting his own judgment as to the best interest of all the stockholders, untrammeled by dictation and unfettered by the obligation of any contract." Luthy v. Ream, 270 IIl. x70, I8r, xro N.E. 373,376 (rgx5).

${ }^{6}$ See 7 St. John's L. Rev. 218, 225 (I933) for an excellent discussion, concluding that, in the absence of statutes, no prohibitions should be put on the sale of voting rights.

7 See 5 Fletcher, Corporations \& 2066, p.925 (r93I). In public elections voters have no duty to vote for the best interests of each other; the selling of votes is instead prohibited because of possible dangers to the government. Perhaps it may be argued that the same reasoning should prohibit the sale of votes in corporate elections; but it is believed that such intangible fears are not a sufficient basis for a doctrine which endangers the validity of voting agreements and voting trusts.

${ }^{8}$ In Nickolopoulos v. Sarantis, Io2 N.J. Eq. 585, I4I Atl. 792 (I928), all the stockholders induced the plaintiff to put new money into the corporation by promising him a $5 \circ$ per cent vote although he owned only 25 per cent of the stock. A statute provided that every corporation could determine by its charter or by-laws the number of shares which should entitle the [Footnote 8 continued on page 643 ]

${ }^{9}$ White v. Snell, 35 Utah 434, roo Pac. 927 (Igog). 
In Mlinois there is an apparent justification for the doctrine other than abstract fears of possible fraud or injury to other stockholders. Section 3, Article 2, of the Illinois Constitution, providing in part that "every stockholder shall have the right to vote," has been construed to mean that every stockholder must be given the right to vote ${ }^{\mathrm{To}}$ and that the corporation can give such a right only to stockholders. ${ }^{\mathrm{II}}$ As a corollary, in Luthy v. Ream, $_{\mathrm{rz}}^{\mathrm{Iz}}$ a voting trust in which the trustee was not directed by the cestuis was held invalid as an illegal attempt to separate the cestuis' voting rights from their beneficial ownership. The court emphasized that "the power to vote for directors can be exercised only by stockholders in person or by proxy, and they cannot be deprived

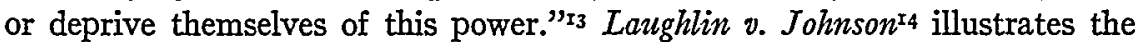
effect Luthy v. Ream has had on voting contracts and the fact that it is ever a potential threat to their validity. In the former case, a suit for damages, the appellate court held void as a separation of control from ownership a contract whereby one stockholder sold to another all his beneficial interest in certain shares but retained his voting rights and in addition secured the voting rights of other stock owned by the buyer. ${ }^{15}$ This result is directly opposed to a supreme court decision which antedates Luthy v. Ream, holding that a contract between subscribers whereby one group should vote another group's stock for

[ [Footnote 8 continued from page 642]

stockholders to one or more votes. Specific performance was denied and the contract was held void because not put in the by-laws or charter, and the court said the agreement "was a fraud on the corporation and on those dealing with it." This case illustrates how an intangible fear may force the courts to disregard practical considerations, with the result that unethical conduct by stockholders is sanctioned. In practice creditors rarely know who has actual voting control and can seldom be said to rely upon it. Furthermore, it is difficult to find actual injury to stockholders where all of them are parties to the contract. The decision is especially doubtful because of the statute. $C f$. Kantzler v. Bensinger, 214 IIl. 589, 73 N.E. 874 (Igo5), granting damages for the breach of a contract among all the stockholders of a closed corporation whereby they bound themselves to elect certain persons directors and officers at fixed salaries. Although this decision did not consider the problem of separating voting rights from the beneficial ownership of stock, it stressed the desirability of sustaining voting agreements among stockholders of closed corporations and gave no weight to arguments similar to those advanced by the court in Nickolopoulos v. Sarantis. See note 33 infra.

ro People v. Emmerson, 302 Ill. 300, r34 N.E. 707 (r922) (preferred stock must have voting rights).

I Durkee v. People, I55 Ill. 354, 40 N.E. 626 (I895) (bondholders cannot be given voting rights).

${ }_{22} 27$ Ill. I70, rIO N.E. 373 (IgI5). $\quad{ }^{23} 270$ Ill. I70, I78, IIO N.E. 373,375 (rgr5).

${ }^{4} 230$ Ill. App. 25 (1907).

I5 In People v. Pyle, 235 Ill. App. 532 (1924), an agreement among all the stockholders that there should be no change in the appointment of one of their number as general manager without the consent of all, was held illegal. One of the reasons given for the decision was that the agreement deprived the stockholders of their constitutional right to vote. But the court confused this objection with that of binding the directors' powers. If contracts to elect directors are not illegal as depriving stockholders of the right to vote (see note 18 infra) it is difficult to see why the agreement in People v. Pyle should have been considered illegal on this ground. Cf. Fitzgerald v. Christy, 242 IIl. App. 343 (x926) (facts stated in note 35 infra). 
eight years was a valid proxy. ${ }^{16}$ In this case the court said "it is none of the business of one stockholder for whom the votes of another shall be cast. In this respect, each is at full liberty to act as his judgment or interest may dictate." Although Luthy v. Ream clearly denies the right of a stockholder to sell his vote, decisions prior and subsequent to it have definitely established the validity of contracts whereby a group of stockholders agree to cast their votes as a unit for the election of certain persons as directors and officers. ${ }^{.8}$ Sustaining these contracts forces the parties to vote according to their agreement and creates a separation of voting power from ownership as effectively as a sale of votes. The only difference between the two is one of the degree of separation-they represent the two extremes possible. If in a contract to elect directors there is also a provision that one stockholder shall, in the absence of another, vote the latter's shares at all meetings, the separation is more complete but the contract is still legally binding. ${ }^{19} \mathrm{~A}$ still greater degree of separation has been approved by the appellate court in temporarily enjoining the breach of a contract between the owner of stock and one having an equitable interest therein by which they agreed to give a third party the right to vote for ten years as he desired. ${ }^{20}$ That stockholders may within limits deprive themselves of the right to vote is

${ }^{16}$ Ryder v. Alton, $x_{3}$ Ill. 516 ( $185 \mathrm{r}$ ). This case was apparently unknown to the appellate court deciding Laughlin v. Johnson, 230 Ill. App. 25 (1907).

${ }^{17}{ }_{13}$ Ill. 516, 521 (I851). Cf. Chicago Macaroni Co. v. Boggiano, 202 Ill. 312, 316, 67 N.E. I7, I9 (x903) and Blinn v. Riggs, rro Ill. App. 37, 49 (1903) holding that a stockholder represents his own, and no other, interests in voting. But in Luthy v. Ream, 270 IIl. I70, I78, I IO N.E. 373,375 (I9I5), the court said stockholders cannot deprive themselves of the right to vote because they "cannot evade the duty imposed upon them by the law of using their powers as stockholders for the general welfare of the corporation and the general interest of its stockholders." (Perhaps this restatement of the reasons given by courts in the absence of a statutory or constitutional basis for prohibiting the separating of voting powers from beneficial ownership indicates that Luthy v. Ream was not decided on constitutional grounds, although the court purports so to justify its decision.) In Brady v. Bean, 22I Ill. App. 279 (rg2I), the directors were contemplating a sale of all assets for an amount sufficient to pay all the corporation's debts but which would leave nothing for the stockholders. The defendant was a creditor and promised the plaintiff a certain sum if he did not object to the sale. In a suit to recover the sum promised, the contract was held void as influencing the plaintiff's decision in a'matter in which he owed the other stockholders a duty to use his judgment unbiased by any private considerations, and it was immaterial that neither plaintiff nor defendant was a director or officer but that both were merely stockholders. The soundness of this decision perhaps may be open to criticism; but it illustrates the far reaching effect of prohibiting a stockholder from depriving himself of the right to vote because he owes a duty to other stockholders.

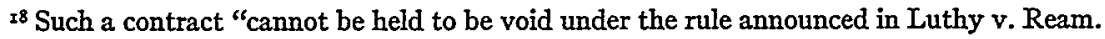
.... It does not divest or attempt to divest .... [the stockholder] of his control or ownership of his stock, or his right to vote the same, except that . . . it is provided that the parties .... shall vote their stock for each other for directors and for no other person or persons." Thompson v. J. D. Thompson Carnation Co., 279 IIl. 54, 58, Ir6 N.E. 648, 649 (I9I7); Faulds v. Yates, 57 Ill. $4 \mathrm{I} 6$ (I87O).

${ }^{19}$ Thompson v. J. D. Thompson Carnation Co., 279 Ill. 54, II6 N.E. 648 (I9I7).

${ }^{20}$ Rider v. Rider, II4 Ill. App. 202 (IgO4) (temporary injunction). 
emphasized by the distinction made by the supreme court between the voting trust in Luthy v. Ream and that which it had formerly held valid in Venner $v$. Railroad. ${ }^{2 x}$

The trust in Luthy v. Ream gave the trustee the absolute right to vote the majority of the stock in the corporation for a period of ten years independent of any control by the cestuis. In declaring this trust invalid as an attempt to give an irrevocable proxy not coupled with an interest, Venner $v$. Railroad was distinguished on the ground that there the stockholders controlled the voting of the trustee and accordingly an election of directors under the trust was really an election by the stockholders through their proxies. The court repeatedly emphasized that the difficulty with the trust in Luthy v. Ream was that "the voting power of the stock is absolutely separated from its ownership for a term of years, so that the real owners of the property are during that time entirely divested of its management and control or of any participation therein."2z It is evident from this language that the court would permit a certain amount of separation of voting rights from ownership; but there was no attempt to lay down a definite standard for determining what amount will invalidate an agreement.

It is an open question whether Luthy $v$. Ream, in spite of language implying that it was decided on constitutional grounds, ${ }^{23}$ was not overruled by $B a b c o c k$ v. Chicago Ry. Co. ${ }^{24}$ The Babcock case upheld a voting trust identical to that in Luthy v. Ream in so far as the trustees had absolute control in voting the stock; but three differences existed, all of which were stressed by the court in distinguishing the two cases. The purpose of the Babcock trust was to reorganize a corporation; the corporation was a public utility in which the city of Chicago was vitally interested; and the new stock was given directly to the depositaries of the old stock who in turn issued participating certificates to the old stock-

${ }^{21} 258$ Ill. 523 , IOI N.E. 949 (r9I3). The trustee was to vote in accordance with the directions of a majority of the ceshitis. While superficially it may appear that no controlling analogy can be drawn between voting trusts and voting agreements, it is significant that in holding valid the trust in Venner v. Railroad the court relied upon the decision in Faulds v. Yates, 57 Ill. 416 ( 1870 ), which sustained a contract (not a trust) among three majority stockholders to cast all their votes as a unit for directors and officers selected by ballot among themselves. (Prior to Venner v. Railroad, the appellate court recognized the similarity between Faulds v. Yates and a trust like that in the Venner case. Gray v. Bloomington \& Normal Ry., $120 \mathrm{Ill}$. App. 159 (1905).)

The similarity between these two cases illustrates that, aside from the technical difference that in a voting trust the legal title is in the trustee rather than in the stockholders, voting trusts and voting agreements should, and seemingly are in Illinois, governed by identical rules in determining the extent to which voting rights may be separated from beneficial ownership. But see 5 Fletcher, Corporations $\$ 2064$, p. I99 (I93I): “. . . . [voting agreements] are distinct from voting trusts, and are not controlled by the same principles."

22 270 IIl. 170, 177, I10 N.E. 373, 375 (Igr5) (italics added).

${ }^{23}$ Luthy v. Ream, 270 Ill. I70, I78, rro N.E. 373, 375 (r9x5); People v. Emmerson, 302 Ill. $300,307,134$ N.E. 707,710 (r922).

${ }^{24} 325$ Ill. I6, I55 N.E. 773 (1927). 
holders. The court said there was no question of the giving of an irrevocable proxy as in Luthy v. Ream since the participating certificate holders never had title to the new stock; and even assuming the existence of a proxy question, since the trustees were holding the stock for the benefit of the bondholders, the proxies were irrevocable because coupled with an interest. The technical distinction as to the ownership of the new stock prior to the creation of the trust seems to be merely a justification of a preconceived result. But the analysis of the trust as consisting of reciprocal proxies made irrevocable because they secured the interests of creditors is supported by the modern tendency to sustain voting trusts which serve any valid purpose.25 The protection of the interests of existing stockholders should furnish a similar ground for validating all voting trusts; and the appellate court ${ }^{26}$ so held by assuming that the Babcock case overruled Luthy v. Ream. If the latter no longer is good law, every kind of voting agreement should be valid, no matter how great the separation of voting rights from beneficial ownership. This should include even a contract to sell votes to outsiders, for Luthy v. Ream is the only supreme court decision which has declared that stockholders have no power to deprive themselves of voting rights and is the only real obstacle to the recognition of the mpracticability of the common law doctrine by the Mllinois court. ${ }^{27}$

\section{II}

The legality of stockholders' contracts which prevent the directors from freely exercising their judgment in the management of the corporation is now the subject of inquiry. Since stockholders must necessarily combine to elect directors, it is well established that a contract among stockholders for that purpose alone is binding on the parties. ${ }^{28}$. If the agreement, however, provides for the election of officers, or the declaration of dividends, or otherwise limits the discretion of the directors, it represents an assumption by the stockholders of powers ordinarily withheld from them. The principal problem raised by such a contract is the protection of minority interests.

${ }^{25} 24$ Mich. L. Rev. 344 (I926). There would seem to be no need to talk of irrevocable proxies in sustaining a voting trust for the same result can be reached on ordinary trust principles, and the Illinois Supreme Court so intimates.

${ }^{26}$ Boyle v. Smith, $248 \mathrm{Ill}$. App. $57,82(\mathrm{xg} 28)$ (sustaining the validity of a voting trust created to maintain the status quo of a family corporation).

${ }^{27}$ The decisions construing the constitution to prevent voting bonds (Durkee v. People, I55 IIl. 354, 40 N.E. 626 (I895)), and non-voting stock (People v. Emmerson, 302 Ill. 300 , I34 N.E. 707 (I922)) hold only that all stock must have a right to vote and that stockholders alone can vote in the first instance. But they do not necessarily prohibit stockholders' depriving themselves of voting rights and retaining beneficial ownership. They have been so construed only because of Luthy v. Ream. The prohibition of non-voting stock and voting bonds was aimed at preventing a different kind of control than is presented by voting agreements.

${ }^{28} 5$ Fletcher, Corporations $\S 2064$, p. I94 (I93I). 
If there is no minority, protection of the shareholders' interests from the danger of future dissension warrants provisions as broad as the parties desire. An agreement among all the stockholders can exist only in a closed corporation where the stockholders usually are also directors, and the identity of management and ownership is so complete that the independent judgment of directors is a fiction. The stockholders in their relations to each other think and act as partners; ${ }^{29}$ the law should recognize this intimacy and permit them to contract among themselves as partners can..$^{30}$ The exercise by the directors of their judgment for the best interests of the corporation is consonant with a duty of discharging an agreement adopted by all the interested stockholders. This position is approved by the Tllinois Business Corporation Act, ${ }^{3 x}$ which provides that by appropriate charter provisions any action by the board of directors without its unanimous vote can be prevented; in most closed corporations this would require unanimous approval by the stockholders. The enforcement of such a contract should, of course, be subject to the rights of existing creditors, but, as was said in Kantzler v. Bensinger, ${ }^{32}$ "It will be time enough to consider the rights of subsequent stockholders and creditors of the corporation when they are before .... [the court] complaining." No supreme court case has arisen in Illinois where the contract did more than designate the officers and directors to be elected and fix their salaries, but in giving damages for a breach of such an agreement, the court implied that it would sustain one going much further. ${ }^{33}$

In People v. Pyle, 34 however, the appellate court held invalid a contract among all the stockholders, whereby one of the parties was to be elected general manager removable only by unanimous consent. This decision seems to be contrary not only to the language in Kantzler v. Bensinger, but also to two appellate

29 In upholding the validity of a contract among all stockholders denying each the right to acquire more than ten shares of stock in the corporation, the supreme court has recognized that in closed corporations the stockholders are, in practice, much like partners and has intimated that this should be taken into consideration in determining the validity of contracts that they make among themselves. Hladovic v. Paul, 222 Ill. $254,263,78$ N.E. 6x9, 622 (I906). See also People v. Galskis, 233 Ill. App. 414, 420 (I924).

${ }^{30}$ Partners may contract as they see fit, limited only by the restriction that their intent shall not be in fact fraudulent. Uniform Partnership Act $\$ \S 9,10,18,20,21$.

${ }^{3 x}$ Section 37; Ill. State Bar Stats. I935, c. 32, § 37 .

${ }^{32} 214$ Ill. $589,600,73$ N.E. 874,878 (1905).

33 In Kantzler v. Bensinger, 214 Ill. 589 (1905), at page 598, the court said, "The contract was entered into by all the stockholders of the corporation, and while it may not have bound the board of directors afterwards elected, we think there is no reason in law why it should not be held to be binding upon the defendants and enforceable against them .... It was open to the parties to make any arrangements with regard to the management of the corporation mutually agreeable to them. No other persons had any interest in the stock and no one else could complain" (Italics added). In Wabash Ry. v. American Refrigerator Transit Co., 7 F. (2d) 335 (C.C.A. 8th I925), cert. den. 270 U.S. 643 (I926), a contract among all the stockholders distributing the earnings of the corporation in a fixed manner was upheld.

34235 IIl. App. 532 (I924). 
court cases which distinguish between contracts binding all the stockholders and those merely binding the majority. 35

Where only a majority of the stockholders combine for the purpose of electing directors, the courts still agree that the contract is enforceable..$^{36}$ When the agreement, however, limits the powers usually exercised by the directors, the necessity of protecting minority stockholders raises serious difficulties. It is said that taking away the liberty of the directors to exercise their discretion in management removes the last defense of the dissenters against the machinations of the majority. ${ }^{37}$ In practice, however, the fact that the majority of the stockholders elect the directors results in majority domination of the management, at least to the extent of determining the officers, salaries, and broad policies of the corporation. Even in the exceptional case in which the directors disregard the desires of controlling stockholders, this check on the arbitrary will of those who would otherwise control the corporation can last only until the following election. An illustrative case is $M c Q u a d e$ v. Stoneham, ${ }^{38}$ involving a contract among the three majority stockholders by which they agreed to elect themselves officers and directors at fixed salaries. The New York court held the contract unenforceable even for damages, on the ground that any liability whatever might exert an effect deleterious to the minority upon the judgment of the directors. ${ }^{39}$ Lehman, J., dissenting, said "public policy should be governed by facts, not abstractions," 40 and, recognizing the usual domination by majority stockholders, contended that the need of stockholders to protect their interest by contracts far outweighed the advantages of any check that the directors exert upon the most numerous class of stockholders. The Illinois Supreme Court has upheld contracts among the majority stockholders to elect directors and officers, and from the strong language used it seems that provisions fixing sal-

35 In Teich v. Kaufman, I74 Ill. App. 306 (IgI2), in holding a contract between majority stockholders void, the court distinguished Kantzler v. Bensinger on the ground that the latter was an agreement among all the stockholders. The distinction was approved in Fitzgerald v. Christy, 242 Ill. App. 343, 358 (r926), where a temporary injunction was granted to prevent the breach of a contract among all the stockholders giving the complainant the power to veto any change in officers or salaries or any proposal to declare dividends or incur expenses.

${ }^{36}$ Faulds v. Yates, 57 Ill. 4 I6 (I87O); Fitzgerald v. Christy, 242 Ill. App. 343 (I926); Thompson v. J. D. Thompson Carnation Co., 279 Ill. 54, II6 N.E. 648 (I9I7).

37 Manson v. Curtis, 223 N.Y. $3^{1} 3$, x I 9 N.E. 559 (xgr8).

${ }^{38} 263$ N.Y. 325, 189 N.E. 234 (I934).

39 In this case the contract also provided that no change in the policy of the business could be made without a unanimous vote of the contracting parties. This provision seemed not to trouble either the majority or dissent; the whole issue apparently was whether the contract could provide for officers and salaries. The court unanimously agreed that if only directors had been provided for, the contract would have been upheld. If the extent to which the majority stockholders may contract to control the management must be limited by an arbitrary line, it would seem that the logical point is that of electing directors; anything beyond this restrains the exercise of the directors' judgment.

${ }^{40} 263$ N.Y. $325,338,189$ N.E. 234,240 (I934). 
aries would also be approved.4ז This result has been assumed by the appellate court in a memorandum opinion. ${ }^{2}$ The tllinois view seems definitely preferable to that of the majority in the McQuade case. ${ }^{43}$

Contracts among the majority stockholders providing for greater limitations upon the managerial powers of the directors than the election of officers have never been before the Tlinois Supreme Court. The appellate court, in Teich $v$. Kanfman, ${ }^{44}$ had before it a contract which provided for the election of certain officers and directors at fixed salaries, and also for the employment of two of the contracting parties as managing directors. In a suit by the two for specific performance, the contract was held to be illegal. Apparently at the time the stockholders executed the agreement they were also directors. The decision may be explained on either of two theories: (I) that any such contract made by majority stockholders while in the position of directors was illegal; (2) that the agreement too greatly controlled their judgment as directors. Undoubtedly the fact that a contract is executed by stockholders who at the time are in the fiduciary position of directors is conducive to a hasty conclusion that the contract is void.45-But most contracts among majority stockholders include one or more directors. To attach the consequence of illegality to an agreement on this ground alone would be to limit voting agreements almost entirely to pre-incorporation transactions. The Teich case seems to be correct only on the theory that designating the managing director of the corporation tends to restrict the directors' powers too greatly. This is not a point on which dogmatic rules can

4. Thompson v. J. D. Thompson Carnation Co., 279 Ill. 54, II6 N.E. 648 (I9I7); Faulds v. Yates, $57 \mathrm{Ml}$. 416, 42I (I870), where the court said, "It is strange that a man cannot, for honest purposes, unite with others in the protection and security of his property and rights without liability to the charge of fraud and iniquity. Their interests were identical with the interests of the minority shareholders. .... If they increased the value of their own stock, they also increased the value of all other stock. If they destroyed the stock of others, they also by the same act destroyed their own. It is absurd to suppose that a sane man will ruin himself for the mere pleasure of ruining others."

${ }^{42}$ Horn v. J. O. Nessen Lumber Co., 236 Ill. App. I87 (I925).

${ }^{13}$ For the reasons stated in note $4 \mathrm{I}$ supra, which far outweigh the possible dangers to the minority.

4474 IIl. App. 306 (Igr2).

45 West v. Camden, 135 U.S. 507 ( 1890 ), is frequently cited by courts in holding that directors cannot contract away the power to exercise their independent judgment. In that case the defendant director had agreed to use his influence to keep the plaintiff permanently in the position of vice-president. In a suit for damages, the contract was held void as creating a constant incentive to the defendant to ignore the best interests of the other stockholders by retaining the plaintiff in the position of vice-president. The result of this case was desirable because there was no compensating advantage to the contracting parties as compared to the dangers to the corporation. And the facts are entirely distinguishable from a situation where the majority stockholders, who may at the time be directors, agree to designate each other as officers and thus protect their interests. The facts in Faulds v. Yates, $57 \mathrm{Ill} .416$ (1870), are not clear, but it seems that at least one party to the contract was a director at the time it was executed, and if not, it is unlikely that a different result would have been reached. 
be laid down. What is a proper limitation upon directors' powers will vary with the nature of the corporation and the state of its affairs at the time the contract is executed. Judicial cognizance of this fact would remove the temptation to handle voting agreements by rule of thumb, $4^{6}$ and would substitute a conscious process of balancing the interests of the majority with the risk of injury to noncontracting stockholders. Frequently it falls to directors to decide which of several conflicting but legitimate courses of action they should pursue. The desire of the majority to protect its interests by planning a unified and continuous business policy for guidance of the directors in such situations is natural and should be given effect. ${ }^{47}$

The risk of agreements going beyond the degree of protection which the majority fairly can demand is minimized in closed corporations by the intimacy of the minority groups with the affairs of the corporation, and the courts can amply protect such groups if actual fraud or injury is shown..$^{8}$ In large corporations the courts will perhaps be influenced by the fact that a scattered minority, with no accurate knowledge of corporate activities, needs additional protection. In such cases the process of balancing the advantages against the dangers of such contracts may include a more or less strong presumption of illegality, depending upon the nature of the agreement. Under no circumstances should a party to the contract be able to set up illegality as a defense unless he can prove actual fraud or injury to the corporation.

Assuming the validity of the contract, what remedy have the parties thereto

${ }_{46}^{6}$ As in McQuade v. Stoneham, 263 N.Y. 325 , I89 N.E. 234 (I934), where the line apparently is arbitrarily drawn at provisions for the election of directors, any attempt to control the activities of the directors being void.

${ }^{47} \mathrm{Cf}$. "... . [The court] can see no objection, on the score of public policy, to an agreement between parties about to form a corporation, agreeing upon the general plan upon which it is to be organized and conducted, so long as nothing is provided for inconsistent with the provisions of the statute or immoral in itself." Lorillard v. Clyde, 86 N.Y. 384,389 (r88r), approved in Kantzler v. Bensinger, 2I4 Ill. 589, 599, 73 N.E. 874, 878 (rgo5).

${ }_{48}^{8}$ But see 44 Yale I. J. 873 (I935). In Faulds v. Yates, 57 Ill. 4I6, 42I (I870), the court said, "The agreement complained of was entered into by Faulds and his partners. The noncontracting minority whom he is solicitous to defend and protect have not complained. He cannot invoke their shield to fight imaginary wrongs. The transaction which he, through his counsel, denounces as fraudulent and nefarious, was conceived and consummated by him, as much as by his partners. Every motive which could influence a man for good, should have prompted him to silence.

"If this combination was fraudulent and intended for bad purposes, the stockholders, who are in a minority, and who may have suffered, have ample redress. We prefer to listen to them, before any decision as to their wrongs."

In every case arising in Illinois, the party setting up the illegality of the contract as a defense to his breach was doing so for personal reasons; there seldom has been any concrete evidence to prove that compliance with the contract would not react to the best interests of the corporation. For a typical case where, if the court had not sustained the contract, the stockholder attacking it would have succeeded in unethical conduct to the great detriment of the other contracting parties, see Fitzgerald v. Christy, 242 Ill. App. 343 (I926). 
in the event of a breach? Where the contract is to elect directors and officers, specific performance is denied by some courts on the theory that equanimity among the executives is necessary for the successful functioning of a corporation. ${ }^{9}$ However true this may be, damages frequently are so inadequate that specific performance is highly desirable. The Illinois courts apparently are not averse to giving such relief.50 Assuming that specific performance can be obtained in Illinois, it becomes important to prevent a transfer of the stock into the hands of persons against whom the contract is not enforceable. Provisions in the contract requiring the owner of stock to offer it to the other contracting parties at a fair price before selling to third persons are valid as a reasonable restraint on the freedom of alienation; ${ }^{5 x}$ and where such restraint is printed on the face of the stock certificate it gives notice to all purchasers who take subject to the condition. ${ }^{22}$

49 See the decision of the trial court in McQuade v. Stoneham, 142 Misc. 842, 849-5I, 256 N.Y.S. $431,440-1$ (1932).

so The contract among the majority stockholders for the election of directors and offcers "is of such a character that we think it could have been specifically enforced by any of the parties thereto in case of an attempted breach." Thompson v. J. D. Thompson Carnation Co., 279 Ill. 54, II6 N.E. 648 (IgI7) (dictum); see Fitzgerald v. Christy, 242 IIl. App. 343 (1926) (temporary injunction granted).

5x People v. Galskis, 233 Ill. App. 4I4 (I924). A contract among all stockholders, entered in the by-laws and written on stock certificates, that no stockholder should buy or sell any stock without the consent of a majority, was held void as an unreasonable restraint on alienation. People ex rel. Malcom v. Lake Sand Corp., 25I III. App. 499 (I929).

s2 People v. Galskis, 233 Ill. App. 4I4 (I924). 